\title{
Valuation the Fishery Economic Value Limboto Lake Gorontalo Hasim $^{1 *}$, Herwin Mopangga ${ }^{2}$ \\ ${ }^{1}$ Lecturer of Fishery and Science Marine Faculty, State University of Gorontalo, Indonesia \\ ${ }^{2}$ Lecturer of Economic and Business Faculty, State University of Gorontalo, Indonesia
}

\section{Driginal Research Article \\ *Corresponding author Hasim}

\section{Article History}

Received: 10.05 .2018

Accepted: 23.05.2018

Published: 30.05 .2018

DOI:

10.21276/haya.2018.3.5.5

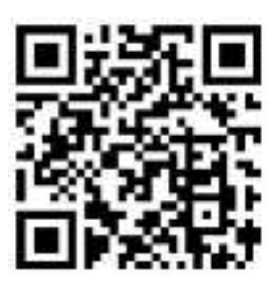

\begin{abstract}
This study aims to calculate the fishery economic value of Limboto Lake including aquaculture, catch, and bibilo fishery. The research was conducted in Limboto Lake area and using survey method that based on questionnaire in collecting data. Respondents were 100 people who determined randomly. The productivity method is an estimate of the ecosystem economic value for a product or service that contributes to the commercial goods production in the market. The results showed that the fishery economic value of Limboto Lake is 51.474.000. 000 IDR / year. More than $50 \%$ of the value is contributed by aquaculture fishery.
\end{abstract}

Keywords: Economic Valuation, Utility, fishery, Limboto lake.

\section{INTRODUCTION}

Economic valuation in this research is used to provide quantitative value in the form of percentage of natural resource yield in Limboto Lake. Various studies on economic valuations related to water and fishery have been conducted by Wilson \& Carpenter [1], Kragt, et al. [2], Admiraal, et al. [3], and it showed different models and approaches. This study simply describes the economic valuations to help local governments recognize the potential of their natural resources. The economic stability of Limboto lake has important role in Gorontalo because the coastal communities in the area have a high economic dependence. Based on the literature study there are 329 RTP with KJA system and 1454 RTP fishermen, while the bibilo fisherman reach 785 RTP. Thus, the entire RTP in Limboto lake is 2569. If each RTP there are two head of household, then there are 5138 households. If the assumption of a household there are 4 members, then the population that has an economic dependence on the lake is 20,552 inhabitants.

The waters of Lake Limboto experience high eutrophication. It is shown by aquatic plants, almost 50 percent of the lake's surface area [4]. According to Boyd [5] that the population of water plants that reach 10-20 percent of the water surface area will complicate the management of fishery. Based on these conditions Limboto lake by KLH entered in 10 lakes classified as critical.

Since 1988, fishery experiments have been conducted with floating net in Limboto lake. This aquaculture activity is progressing every year. This is indicated by the number of Karamba Floating Nets (KJA) that incubate the increase. In 1993 the number of KJA 500 units and developed to 1962 units in 2007. While the number of fish farmers is 329 RTP. Generally the type of fish that is maintained is Oreochromis niloticus, Oreochromis musambica and carpio Cyrprinus carpio [6].

Several studies have reported that intensive cultivation and nutrient enrichment have a potential impact on changes in water quality $[7,5]$. Furthermore,
Haven et al. [8] and Johansson [6] stated that aquaculture in the lake has high organic waste and play a role in eutrophication.

Governor of Gorontalo expressed his thoughts to make Limboto Lake as the area ofaquaculture Industry. The consideration is the commodity market of aquaculture is very prospects outside. The view of rent seeking to capitalize the lake through aquaculture is important to be prioritized. Because in the critical condition of Limboto lake, increasing the burden of cultivating aquaculture produces an ecological threat. Therefore, research needs to be conducted to assess the fishery economic value of Limboto Lake as a basis in formulating the lake management policy that supports sustainable fishery.

\section{RESEARCH METHODS}

This research is done by survey method that is using questioner as instrument of data collection. Data collection techniques were conducted in interviews. The analysis used is Productivity Method. The productivity method is an estimate of the ecosystem economic value 
for product or service that contributes to the commercial goods production on the market [9]. The stages in calculating productivity method are calculating loss in productivity, defensive expenditure and replacement cost or restoration cost of an environmental service. Productivity method is used to determine the quality of the environment directly, whether it affects the production cost of the marketed natural resources. The benefit of the productivity method has limited data requirements and relevant data is available. Meanwhile, this method relatively easy to be implemented. The simple formula used in the productivity method is as follows:

Value of Productivity SDA $=(\Sigma$ Production $/$ ha $\mathrm{x} \mathrm{P})-$ (Input Cost)

\section{Information}

Value of SDA Productivity: The value of productivity from natural resources.

$\Sigma$ Production: Total production of commodities (hectare)
P: Commodity Prices (IDR / Kg)

Input Cost: The cost of non-natural resources.

\section{RESULTS AND DISCUSSION}

The value of natural resources productivity in fishery sector at Limboto lake obtained with sum up productivity value from different type freshwater fishery. Those are included fishery catch, fishery bibilo and aquaculture. It need to know that fishery bibilo is the one of traditional fishery catch in Limboto lake. Its fishery use grass as a place in gathering another fish. Limboto Lake obtained from production value per day/harvest season reduced with input costs per day/harvest season. The input cost for each type freshwater fishery obtained the average cost incurred by the fisherman/farmers in one arrest/harvest season. However, the input cost composed from cost seeds/seeding fish, cost feed, cost harvest, cost tool catch (boats, nets and fishing rods, cost care tool catch, cost for results, cost transportation (fuel) and tax. It could be seen in table 1 .

Table-1: The Value of Natural Resource Productivity in Freshwater Fishery Sector Per day/Harvest Season in Limboto lake area

\begin{tabular}{|l|c|c|c|}
\hline $\begin{array}{c}\text { Freshwater } \\
\text { Fishery }\end{array}$ & Production Value & $\begin{array}{c}\text { Input Cost } \\
\text { ( IDR ) }\end{array}$ & $\begin{array}{c}\text { Value of Productivity } \\
\text { ( IDR ) }\end{array}$ \\
\hline Catch & $30.000,00 /$ Day & $15.000,00 /$ Day & $15.000,00 /$ Day \\
\hline Bibilo $*$ & $100.000,00 /$ Day & $15.000,00 /$ Day & $85.000,00 /$ Day \\
\hline Aquaculture & $9,000,000.00 /$ Season & $4.000 .000,00 /$ Season & $5.000 .000,00 /$ Season \\
\hline
\end{tabular}

Source: Primary Data, 2014.

* Bibilo is a type of traditional fishing by using grass as a medium.

Based on the calculation above, the largest type of fishery is bibilo 85.000 IDR and the smallest is catch 15.000 IDR. The aquaculture fishery is done per harvest season. One harvest season in aquaculture is four months. The value of natural resources productivity of freshwater fishery sector per harvest season for the type of aquaculture is 5.000.000 IDR.

The value of natural resources productivity in freshwater fishery sector per year is obtained from multiplication of productivity value per day / harvest season, the number of catches per year and the number of livelihoods as fishermen. The total value of natural resources productivity of freshwater fishery sector per year is derived from the sum of the value of natural resource productivity per year of all kinds of freshwater fishery. The total value of natural resource productivity of freshwater fishery sector in Limboto Lake area can be seen in Table 2.

Table-2: Total Value of Natural Resource Productivity in Freshwater Fishery Sector at Limboto lake area

\begin{tabular}{|l|c|c|c|c|}
\hline $\begin{array}{c}\text { Freshwater } \\
\text { Fishery }\end{array}$ & $\begin{array}{c}\text { Value } \\
\text { Productivity } \\
\text { (IDR ) }\end{array}$ & $\begin{array}{c}\text { amount } \\
\text { Catch / } \\
\text { Year }\end{array}$ & $\begin{array}{c}\text { amount } \\
\text { Population } \\
\text { Livelihood }\end{array}$ & $\begin{array}{c}\text { Value of Productivity } \\
\text { ( IDR / Year ) }\end{array}$ \\
\hline Catch & $15.000,00 /$ Day & 300 & 1.096 & $4,932,000,000.00$ \\
\hline Bibilo * & $85.000,00 /$ Day & 300 & 688 & $17,544,000,000.00$ \\
\hline Aquaculture & $\begin{array}{c}5.000 .000,00 \\
\text { / Season }\end{array}$ & 3 & 2,064 & $30.960 .000 .000,00$ \\
\hline \multicolumn{4}{|c|}{ Total } \\
\hline
\end{tabular}

Source: Primary Data, 2014.

* Bibilo is type fishery catch traditional with use grass as a medium.

Based on the calculation above, the largest is aquaculture 30.960 .000 .000 IDR. and the smallest is catch 4.932.000.000 IDR. However, other types is bibilo 17.544.000.000 IDR. Based on the result of the sum of the value of natural resource productivity per year for all freshwater fishery, the total value is 53.436.000.000 IDR. The small value happened due to the decreasing number of fish catch because over 
fishing and there is a sallow Limboto lake because of sedimentation.

The value of natural resource productivity per year of all types of freshwater fisheries, has not been reduced by the value of water for this type of aquaculture. The value of water for this type of aquaculture is not included in the calculation of the value of natural resource productivity of the freshwater fishery sector because the water usage is the direct use of water categorized as the calculation of water value for freshwater fishery production [10]. Therefore, the value of water for aquaculture species is included in the calculation of the total value of water in the Limboto Lake area. The total value of natural resource productivity of freshwater fishery sector in Limboto Lake area after minus water value for cultivated fishery species can be seen in Table 3 .

\section{Table-3: The Value of Natural Resource Productivity in Freshwater Fishery Sector in Limboto lake area after} deducting the water value for aquaculture

\begin{tabular}{|c|c|}
\hline Freshwater Fishery & $\begin{array}{c}\text { Value of Productivity } \\
\text { ( IDR / Year ) }\end{array}$ \\
\hline Catch & $4,932,000,000.00$ \\
\hline Bibilo $*$ & $17,544,000,000.00$ \\
\hline Aquaculture & $28.998 .000 .000,00$ \\
\hline Total & $51.474 .000 .000,00$ \\
\hline Source: Primary Data, 2014.
\end{tabular}

* Bibilo is a type of traditional fishing by using grass as a medium.

\begin{abstract}
The calculation of the water value from aquaculture uses the water residual value calculation. The calculation of water residual value is the simplest way of assessing water that is the value of production of aquaculture species reduced by input cost and divided by the amount of water used per production period. The amount of water per production period for the type of aquaculture in Limboto lake area is $60 \mathrm{~m}^{3} /$ plot. Based on calculations performed, the value of natural resources productivity of freshwater fishery sector per year for aquaculture fishery after minus the water value obtained 28.998.000.000 IDR. Total value of natural resource productivity of freshwater fishery sector per year in Limboto Lake area after minus water value for aquaculture that is 51.474.000.000 IDR.
\end{abstract}

When we viewed from all types of freshwater fisheries most commonly cultivated in the Limboto lake area, then the type of aquaculture and bibilo which has a value of natural resource productivity is large enough. If we viewed from the economic side is very profitable, but on the other hand there are negative things caused by this type of fishery. That is the use of karamba floating net for aquaculture and bibilo which made some locations in Limboto Lake into private or group plots of property. This can lead to horizontal conflicts among fellow fishermen, causing narrowing and silting in Limboto Lake, as well as degradation of water resources quality in Limboto Lake.

\section{CONCLUSION}

Based on the description above, it is concluded that the economic value of Limboto lake for the dominant fishery sector is contributed by the aquaculture is about 56 percent, the low economic value of fishery catch gives information that the potential SDI of Limboto lake decreased.

\section{ACKNOWLEDGEMENT}

The author would like to thank to Ministry of National Education (DIKTI) who has given funding support through grant competition 2014/2015.

\section{REFERENCES}

1. Wilson, M. A., \& Carpenter, S. R. (1999). Economic valuation of freshwater ecosystem services in the United States: 1971-1997. Ecological applications, 9(3), 772-783.

2. Kragt, M. E., Newham, L. T., Bennett, J., \& Jakeman, A. J. (2011). An integrated approach to linking economic valuation and catchment modelling. Environmental Modelling \& Software, 26(1), 92-102.

3. Admiraal, J. F., Wossink, A., de Groot, W. T., \& de Snoo, G. R. (2013). More than total economic value: How to combine economic valuation of biodiversity with ecological resilience. Ecological Economics, 89, 115-122.

4. Sarnita (1993). Laporan hasil penelitian usaha perikanan di Danau Limboto, Sulawesi Utara, Dalam: Kumpulan Hasil-Hasil Penelitian Perikanan Perairan Umum (Danau dan Waduk) Tahun 1992/1993, Sub Balai Penelitian Perikanan Air Tawar Jatiluhur, Badan Litbang Pertanian. 2: 2-23.

5. Boyd, C. E. (1998). Water Quality in Warmeter Fish Ponds. Auburn University Agricultural Experiment Station, Alabama.

6. Tjahjo, D. W. H. (2007). Monograf Sumberdaya Perikanan Danau Limboto. PSPT-BRKP, DKP.

7. Johansson, T., Håkanson, L., Borum, K., \& Persson, J. (1998). Direct flows of phosphorus and suspended matter from a fish farm to wild fish in Lake Southern Bullaren, Sweden. Aquacultural Engineering, 17(2), 111-137.

8. Havens, K. E., Fukushima, T., Xie, P., Iwakuma, T., James, R. T., Takamura, N., ... \& Yamamoto, T. 
(2001). Nutrient dynamics and the eutrophication of shallow lakes Kasumigaura (Japan), Donghu (PR China), and Okeechobee (USA). Environmental Pollution, 111(2), 263-272.

9. Simanjuntak, M. H. S. (2010). Perkiraan Nilai Ekonomi Sumberdaya Alam Productivity Method. [Materi Kuliah Productivity Method]. Program Pascasarjana, Institut Pertanian Bogor. Bogor.

10. Fassio, A., Giupponi, C., Hiederer, R., \& Simota, C. (2005). A decision support tool for simulating the effects of alternative policies affecting water resources: an application at the European scale. Journal of Hydrology, 304(1-4), 462-476. 